\title{
OPTIMALISASI KETERAMPILAN BERPIKIR KRITIS DAN HASIL BELAJAR MELALUI IMPLEMENTASI MODEL DISCOVERY LEARNING
}

\author{
RUMIYATI \\ SMA Negeri 1 Purwanegara, Banjarnegara \\ Email : arumiyati700@gmail.com
}

\begin{abstract}
ABSTRAK
Penelitian ini bertujuan untuk mengoptimalkan keterampilan berpikir kritis dan hasil belajar fisika pada materi Induksi Elektromagnetik melalui implementasi model Discovery Learning. Penelitian ini merupakan Penelitian Tindakan Kelas (PTK) dengan melakukan 2 (dua) siklus tindakan. Setiap siklus dilakukan melalui 4 (empat) tahapan yaitu: (a) perencanaan, (b) pelaksanaan, (c) observasi, dan (d) refleksi. Data keterampilan berpikir kritis dan hasil belajar dikumpulkan dengan cara: observasi, tes dan dokumentasi. Analisis data yang digunakan adalah análisis kualitatif, kuantitatif dan análisis statistik deskriptif. Hasil análisis menunjukkan bahwa implementasi model Discovery Learning dapat mengoptimalkan keterampilan berpikir kritis dan hasil belajar fisika pada materi Induksi Elektromagnetik. Secara kualitatif terjadi optimalisasi nilai rata-rata keterampilan berpikir kritis kategori tinggi pada pra siklus sebesar $37,04 \%$, pada siklus I sebesar $48,15 \%$ dan pada siklus II sebesar 81,48\%. Berdasarkan hasil ini menunjukkan terjadi optimalisasi keterampilan berpikir kritis kategori tinggi peserta didik sebesar 33,33\%. Secara kuantitatif terjadi optimalisasi hasil belajar fisika rata-rata pada pra siklus sebesar 68,15 dengan ketuntasan belajar klasikal sebesar 55,56\%, pada siklus I sebesar 71,02 dengan ketuntasan belajar klasikal sebesar 62,96\% dan pada siklus II sebesar 75,00 dengan ketuntasan belajar klasikal sebesar $81,48 \%$. Berdasarkan hasil ini menunjukkan terjadi optimalisasi rata-rata hasil belajar fisika sebesar 3,98 dan ketuntasan belajar klasikal sebesar 18,52\%. Dengan demikian dapat disimpulkan bahwa implementasi model Discovery Learning dapat mengoptimalkan keterampilan berpikir kritis dan hasil belajar fisika.
\end{abstract}

Kata Kunci: Keterampilan Berpikir Kritis, Hasil Belajar, Discovery Learning

\section{PENDAHULUAN}

Pendidikan merupakan usaha sadar dan terencana untuk mewujudkan suasana belajar dan proses pembelajaran agar peserta didik secara aktif dapat mengembangkan potensi dirinya sehingga memiliki kekuatan spiritual, kecerdasan, kepribadian dan akhlak mulia, serta keterampilan yang diperlukan dirinya, masyarakat, bangsa dan negara sesuai dengan UU Sisdiknas No. 20 Tahun 2003. Pembelajaran yang diharapkan dalam UU Sisdiknas No. 20 Tahun 2003 adalah pembelajaran yang inovatif dan relevan dengan kebutuhan peserta didik dalam pembelajaran. Pembelajaran yang inovatif dapat terlaksana melalui pemilihan model pembelajaran yang tepat sesuai dengan karakter materi pelajaran, peserta didik, sarana prasarana dan berpusat pada siswa (student centered). Dengan demikian proses pembelajaran harus melibatkan peserta didik secara aktif dan kreatif untuk menemukan sendiri konsep/prinsip materi yang akan dipelajari dan tidak hanya menekankan pada aspek kognitif saja, tetapi juga pada aspek psikomotorik dan afektif.

Dalam pembelajaran fisika idealnya peserta didik memiliki keterampilan berpikir kritis yang tinggi untuk merumuskan pertanyaan, mengidentifikasi kesimpulan, memberikan contoh, membuat laporan observasi, mampu mengaplikasikan konsep serta mampu berargumen saat diskusi sebagai indikator peserta didik memiliki keterampilan berpikir kritis. Namun kenyataan di lapangan berbeda karena kemampuan keterampilan berpikir kritis peserta didik termasuk kategori rendah. Hal ini ditunjukkan dari rendahnya proses pembelajaran kondisi awal/pra siklus yang ditandai dengan masalah-masalah sebagai berikut: (a) kemampuan merumuskan pertanyaan, (b) mengidentifikasi kesimpulan, (c) melaporkan hasil observasi, (d) menggunakan argumen saat diskusi pada materi sebelumnya yaitu tentang listrik statis. 
Berdasarkan data pengamatan keterampilan berpikir kritis kondisi awal/ pra siklus diperoleh hasil sebagai berikut: 10 peserta didik atau 37,04\% kategori tinggi, 5 peserta didik atau $18,52 \%$ kategori sedang dan 12 peserta didik atau 44,44\% kategori rendah. Hal ini menunjukkan pembelajaran fisika belum optimal sesuai harapan peneliti. Kondisi ideal yang diharapkan oleh peneliti adalah rata-rata keterampilan berpikir kritis kategori tinggi sebesar $80 \%$. Belum optimalnya keterampilan berpikir kritis ini menyebabkan hasil belajar rendah. Berdasarkan data hasil belajar pada materi sebelumnya tentang Listrik Statis melalui penilaian harian kondisi awal/pra siklus diperoleh hasil rata-rata 68,15 dengan nilai teringgi 85,00, nilai terendah 55 dan ketuntasan belajar klasikal sebesar 55,56\%. Hal ini menunjukkan pembelajaran fisika belum optimal sesuai harapan peneliti. Kondisi ideal yang diharapkan oleh peneliti adalah nilai hasil belajar rata-rata peserta didik sesuai KKM yaitu 70 dengan ketuntasan belajar klasikal minimal $80 \%$.

Dari refleksi pembelajaran yang selama ini dilakukan, keterampilan berpikir kritis dan hasil belajar peserta didik masih dalam kategori rendah disebabkan oleh beberapa hal yaitu: (a) peserta didik kurang dilibatkan secara maksimal dalam proses pembelajaran, (b) pembelajaran masih terpusat pada guru, (c) peserta didik diperlakukan sebagai objek belajar karena hanya menerima ilmu dari guru tanpa dilatih untuk menemukan sendiri konsep/prinsip dan fakta fisika.

Berdasarkan permasalahan tersebut di atas, perlu adanya upaya guru untuk melakukan perbaikan proses pembelajaran yang inovatif dan menarik bagi semua peserta didik melalui penelitian tindakan kelas agar tercapai optimalisasi keterampilan berpikir kritis dan hasil belajar fisika. Penelitian ini diharapkan dapat mengatasi rendahnya (belum optimalnya) keterampilan berpikir kritis dan hasil belajar fisika pada materi Induksi Elektromagnetik melalui implementasi model Discovery Learning. Keterampilan berpikir kritis berarti keterampilan berpikir pada proses pembelajaran yang melibatkan peserta didik mencari tahu dan menilai secara kritis materi yang akan dipelajari serta mampu menyelesaikan suatu permasalahan. Keterampilan berpikir kritis pada proses pembelajaran dilakukan melalui proses kerja ilmiah, yaitu: (a) mengamati, (b) merumuskan hipotesis, (c) merencanakan percobaan, (d) melakukan percobaan, (e) menafsirkan data, (f) memprediksi, (g) menerapkan konsep, (h) berkomunikasi.

Salah satu alternative model pembelajaran yang dapat diimplementasikan untuk memecahkan masalah belum optimalnya (rendahnya) keterampilan berpikir kritis dan hasil belajar fisika adalah model Discovery Learning. Discovery Learning adalah model pembelajaran yang menekankan pada ditemukannya konsep/prinsip yang sebelumnya tidak diketahui berdasarkan masalah yang dihadapkan pada peserta didik yaitu masalah yang sudah direkayasa oleh guru. Dalam mengimplementasikan model Discovery Learning, guru berperan sebagai pembimbing dengan memberikan kesempatan kepada peserta didik untuk belajar secara aktif, sebagaimana pendapat guru harus dapat membimbing dan mengarahkan kegiatan belajar peserta didik sesuai dengan tujuan (Sardiman, 2005:145). Menurut Budiningsih, (2005:43) model pembelajaran Discovery Learning atau penemuan diartikan pula sebagai cara belajar memahami konsep, arti, dan hubungan, melalui proses intuitif untuk akhirnya sampai kepada suatu kesimpulan.

Langkah-langkah model Discovery Learning (Syah,M., 2004) meliputi: (1). Stimulation (Stimulasi/ Pemberian Rangsangan, (2) Problem Statment (Pernyataan/Identifikasi Masalah), (3) Data Colection (Pengumpulan Data), (4) Data Processing (Pengolahan Data), (5) Verification (Pembuktian), (6) Generalization (Menarik Kesimpulan / Generalisasi).

Berdasarkan uraian tersebut di atas, maka fokus pada penelitian ini adalah apakah implementasi model Discovery Learning dapat mengoptimalkan keterampilan berpikir kritis dan hasil belajar fisika pada peserta didik kelas XII SMA IPA.2 tentang materi induksi elektromagnetik?. 


\section{METODE PENELITIAN}

Penelitian ini merupakan penelitian tindakan kelas yang dilakukan melalui proses kerja kolaborasi dengan guru fisika, kepala sekolah dan peneliti. Subyek penelitian ini adalah peserta didik di SMAN 1 Purwanegara kelas XII IPA.2 semester 1 tahun pelajaran 2019/2020 yang berjumlah 27 peserta didik, terdiri dari 7 laki-laki dan 12 perempuan. Sumber data yang digunakan adalah data observasi atau pengamatan, data hasil belajar dan data dokumentasi. Teknik dan alat pengumpulan data yang digunakan adalah teknik tes dan teknik observasi/pengamatan.Teknik tes digunakan untuk mengukur hasil belajar peserta didik. Sedangkan teknik observasi digunakan untuk menganalisis keterampilan berpikir kritis. Dokumentasi yang digunakan adalah dokumen RPP, LKPD, lembar penilaian, lembar observasi, daftar nilai dan dokumen foto kegiatan pembelajaran.

Dalam penelitian ini teknik analisis data menggunakan: (a) Analisis data tes hasil belajar berbentuk statistik deskriptif yaitu membandingkan rata-rata hasil tes dengan indikator kinerja, dan teknik analisis kecenderungan nilai tengah (Central tendency) yaitu dengan mencari nilai rata-rata. (b) Analisis data pengamatan berbentuk deskriptif komparatif yaitu membandingkan keterampilan berpikir kritis pada pra siklus dengan siklus I, kemudian direfleksi dan keterampilan berpikir kritis siklus I dibandingkan dengan siklus II lalu direfleksi. Analisis data pengamatan dilakukan dengan menghitung kemampuan keterampilan berpikir kritis dengan rumus $=$ jumlah aspek yang muncul dari 9 aspek pengamatan. Jumlah aspek pengamatan sebanyak 9 butir pernyataan, hal ini diasumsikan jika peserta didik memperoleh skor $1-3$, maka keterampilan berpikir kritis peserta didik kategori rendah. Jika memperoleh skor $4-6$, maka keterampilan berpikir kritis peserta didik kategori sedang, Jika memperoleh skor 7 - 9, maka keterampilan berpikir kritis peserta didik kategori tinggi. (c) Analisis dokumentasi untuk kondisi awal/pra siklus menggunakan data penilaian harian KD 3.2. Listrik Statis. Optimalisasi keterampilan berpikir kritis diketahui dari hasil observasi atau pengamatan saat pembelajaran berlangsung dari kondisi awal, siklus I dan siklus II. Optimalisasi hasil belajar dihitung menggunakan tes hasil belajar dari kondisi awal, siklus I dan siklus II. Indikator keberhasilan dalam penelitian ini adalah: (1) keterampilan berpikir kritis kategori tinggi peserta didik sebesar $80 \%$ dari seluruh jumlah peserta didik, (2) hasil belajar peserta didik rata-rata $\geq 70$, dengan ketuntasan belajar klasikal sebesar $80 \%$.

Tahapan kegiatan dalam pelaksanaan penelitian ini menggunakan model Stephen Kemmis dan Mc. Taggart dalam Arikunto (2002) dengan dua siklus, dimana setiap siklus terdiri dari empat tahapan yaitu: (1) perencanaan, (2) Tindakan, (3) observasi, (4) refleksi.

Prosedur pelaksanaan penelitian pada siklus I dilakukan melalui tahapan sebagai berikut: Tahap (1) Perencanaan. Pada tahap ini peneliti menetapkan setting dan waktu pelaksanaan, menetapkan materi pembelajaran, membuat surat ijin penelitian, menyusun rancangan penelitian, menyusun RPP lengkap dengan lembar kerja peserta didik (LKPD), Menyusun lembar observasi berupa instrumen observasi, menyusun jurnal kegiatan penelitian, menyusun program tahunan dan program semester, menentukan jadwal pelaksanaan refleksi. Pada tahap menyusun rancangan ada kesepatan antara guru peneliti dan kolaborator. Tahap (2) Pelaksanaan Tindakan. Tahap pelaksanaan tindakan dilakukan dengan pembelajaran di kelas. Pada tahap ini guru peneliti melakukan tindakan menggunakan model Discovery Learning dengan bantuan LKPD dan alat praktikum sesuai skenario pada RPP. Skenario tindakan diupayakan dilaksanakan dengan baik dan wajar. Langkah-langkah implementasi model Discovery Learning dalam RPP meliputi 6 tahap yaitu: stimulation/pemberian rangsangan, problem statment/identifikasi masalah, data collection/pengumpulan data, data processing/pengolahan data, verification/pembuktian, generalization/menarik kesimpulan. Tahap (3) Observasi. Tahap observasi waktunya berjalan bersamaan dengan saat pelaksanaan tindakan sedang berjalan. Pada tahap observasi/pengamatan guru bertindak sebagai peneliti melakukan tindakan sesuai skenario dan melakukan pengamatan serta mencatat semua hal yang diperlukan dan terjadi selama pelaksanaan tindakan berlangsung. Kegiatan pengamatan juga dilakukan oleh kolaborator untuk mengumpulkan data secara cermat tentang pelaksanaan 
skenario tindakan sesuai RPP dan lembar observasi serta dampaknya terhadap proses pembalajaran dan hasil belajar peserta didik. Tahap (4) Refleksi. Tahap refleksi dimaksudkan untuk mengkaji secara menyeluruh tindakan yang telah dilakukan, kemudian melakukan evaluasi untuk penyempurnaan tindakan berikutnya berdasarkan data yang telah terkumpul melalui pengamatan. Refleksi dalam penelitian ini mencakup analisis proses pembelajaran, analisis hasil belajar, analisis kemampuan guru menyusun RPP, analisis kemampuan guru melaksanakan tindakan dalam pembelajaran, membandingkan hasil tindakan dengan indicator keberhasilan dan memutuskan tindakan lanjutan ke siklus II jika ada masalah belum berhasil mencapai indicator keberhasilan. Kegiatan yang dilakukan jika belum mencapai indicator keberhasilan meliputi perencanaan ulang, tindakan ulang dan observasi ulang.

Pada siklus II proses pembelajaran dilakukan melalui tahapan sebagai berikut: tahap (1) Perencanaan. Pada tahap ini peneliti menyusun rancangan penelitian berdasarkan hasil perbaikan dari kelemahan pada siklus I, menyusun RPP lengkap dengan lembar kerja peserta didik (LKPD), menyusun lembar observasi berupa instrumen observasi, menyusun jurnal kegiatan penelitian, menentukan jadwal pelaksanaan refleksi. Pada tahap menyusun instrumen berkonsultasi dengan kolaborator. Tahap (2) Pelaksanaan Tindakan. Tahap pelaksanaan tindakan dilakukan dengan pembelajaran di kelas. Pada tahap ini guru peneliti melakukan tindakan menggunakan model Discovery Learning dengan bantuan LKPD dan alat praktikum sesuai skenario pada RPP dengan penambahan resitasi/tugas. Tahap (3) Observasi. Tahap observasi waktunya bersamaan dengan pelaksanaan proses pembelajaran. Pada tahap observasi/pengamatan guru peneliti dan kolaborator melakukan pengamatan dan mencatat aktivitas belajar peserta didik selama proses pembelajaran melalui lembar observasi. Tahap (4) Refleksi. Tahap refleksi dilakukan untuk evaluasi aktivitas peserta didik selama proses pembelajaran dan evaluasi tes hasil belajar pada akhir siklus. Refleksi dalam PTK ini mencakup analisis proses pembelajaran, analisis hasil belajar, analisis kemampuan guru menyusun RPP, analisis kemampuan guru melaksanakan tindakan dalam pembelajaran, membandingkan hasil tindakan dengan indikator keberhasilan dan memutuskan tindakan selesai sampai siklus II karena tidak ada masalah atau sudah mencapai indicator keberhasilan.

\section{HASIL DAN PEMBAHASAN}

\section{A. Hasil Penelitian}

Penelitian ini dilakukan dalam dua siklus. Hasil penelitian yang diteliti adalah optimalisasi keterampilan berpikir kritis peserta didik dan hasil belajar dengan implementasi model Discovery Learning.

\section{Siklus I}

Pelaksanaan siklus I terdiri dari tiga pertemuan dengan materi yang berbeda setiap pertemuan. Setiap pertemuan terdiri dari: (1) kegiatan pendahuluan, (2) kegiatan inti, dan (3) kegiatan penutup. Kegiatan pendahuluan terdiri dari: (1) guru membuka pelajaran dengan mengucapkan salam, (2) guru mengajak peserta didik berdoa, (3) guru mengecek kehadiran peserta didik, (4) guru mempersiapkan peserta didik secara fisik dan psikis untuk mengikuti pembelajaran, (5) guru melakukan motivasi dan apersepsi, (6) guru menyampaikan kompetensi dan tujuan yang akan dicapai dalam pembelajaran, Kegiatan inti dilakukan sesuai dengan sintak atau langkah-langkah model Discovery Learning yaitu: (1) guru menyajikan gambar/video untuk memusatkan perhatian pada materi sebagai stimulation/pemberian rangsangan, (2) peserta didik melakukan identifikasi sebanyak mungkin pertanyaan yang terkait dengan gambar/video yang ditampilkan, kemudian dirumuskan dalam bentuk hipotesis, (3) peserta didik dibentuk dalam beberapa kelompok yang terdiri dari 4-5 orang untuk melakukan kegiatan eksperimen/eksplorasi dalam pengumpulan data dengan bimbingan guru melalui lembar kerja peserta didik (LKPD) serta anjuran membaca literatur, (4) peserta didik melakukan diskusi kelompok dalam pengolahan data hasil eksperimen, diklasifikasi untuk pembentukan konsep dan kesimpulan, (5) peserta didik mempresentasikan pembuktian hasil eksperimen di depan 
kelas, (6) peserta didik bersama guru menarik kesimpulan materi pembelajaran. Kegiatan penutup terdiri dari: (1) guru dan peserta didik merefleksi kegiatan pembelajaran, (2) guru memberikan penghargaan berupa pujian atau bentuk lain kepada kelompok yang kinerjanya baik, (3) guru memberikan tugas untuk membuat laporan hasil eksperimen, (4) guru mengingatkan peserta didik untuk membaca materi pertemuan berikutnya, (4) guru menutup kegiatan pembelajaran dengan mengucapkan salam.

Pelaksanaan observasi oleh kolaborator bersama peneliti dilakukan selama pelaksanaan proses pembelajaran berlangsung untuk memperoleh data keterampilan berpikir kritis peserta didik dan untuk memperoleh data guru membuat RPP serta data guru melaksanakan pembelajaran dengan Discovery Learning. Pelaksanaan penilaian hasil belajar dilakukan melalui tes pada pertemuan terakhir (ke-3) tiap siklus. Setelah pertemuan terakhir tiap siklus dilakukan refleksi untuk mengetahui kekurangan-kekurangan yang terjadi selama proses pembelajaran sebagai bahan perbaikan pada siklus selanjutnya. Berdasarkan hasil observasi keterampilan berpikir kritis selama proses pembelajaran siklus I diperoleh data sebagaimana tampak pada table 1 di bawah ini.

Tabel 1. Data Kategori Keterampilan Berpikir Kritis Pada Siklus I

\begin{tabular}{ccccc}
\hline No. & Skor Perolehan & Frekuensi & \% & Kategori \\
\hline 1. & $7-9$ & 13 & 48,15 & Tinggi \\
2. & $4-6$ & 11 & 40,74 & Sedang \\
3. & $1-3$ & 3 & 11,11 & Rendah \\
& Jumlah & $\mathbf{2 7}$ & $\mathbf{1 0 0}$ & \\
\hline
\end{tabular}

Berdasarkan tabel 1 di atas menunjukkan bahwa implementasi model Discovery Learning pada siklus I belum nampak optimalisasi keterampilan berpikir kritis yang signifikan. Dari 27 peserta didik hanya13 peserta didik yang memiliki keterampilan berpikir kritis kategori tinggi. Hal ini disebabkan peserta didik belum terbiasa dengan model Discovery Learning, sulit mengidentifikasi kesimpulan, dan kurang menggunakan argumen saat diskusi kelompok.

Hasil analisis data penilaian hasil belajar peserta didik kelas XII IPA.2 pada mata pelajaran fisika dalam proses pembelajaran siklus I diperoleh data sebagaimana tampak pada tabel 2 di bawah ini.

Tabel 2. Hasil Belajar pada Siklus I

\begin{tabular}{clc}
\hline No. & \multicolumn{1}{c}{ Kriteria } & Hasil Siklus I \\
\hline 1. & Nilai Tertinggi & 90,00 \\
2. & Nilai Terendah & 62,50 \\
3. & Nilai Rerata (Rata-rata) & 71,02 \\
4. & Jumlah peserta didik yang tuntas & 17 \\
5. & Jumlah peserta didik yang tidak tuntas & 10 \\
6 & Prosentase Ketuntasan Belajar & $\mathbf{6 2 , 9 6 \%}$ \\
\hline
\end{tabular}

Berdasarkan tabel 2 di atas terlihat bahwa hasil belajar peserta didik pada siklus I untuk nilai rata-rata sudah nampak optimal sebesar 71,02 dengan ketuntasan belajar 62,96\%, namun belum mencapai kriteria ketuntasan belajar klasikal yang ditetapkan yaitu $80 \%$ sebagai indikator keberhasilan penelitian, sehingga akan ditindaklajuti dengan perbaikan pada siklus II. Belum tercapainya ketuntasan belajar klasikal peserta didik sebesar $80 \%$ diperkirakan karena pembelajaran dengan implementasi model Discovery Learning belum familiar, sehingga perlu waktu agar peserta didik memahami dan mendalami model Discovery Learning.

Berdasarkan hasil refleksi dari data akhir siklus I di atas menunjukkan bahwa keterampilan berpikir kritis kategori tinggi baru mencapai 48,15\% sehingga belum berhasil 
mencapai target $80 \%$. Hasil belajar juga baru mencapai rerata 71,02 dengan ketuntasan belajar klasikal sebesar 62,96\%, sehingga belum mencapai target indikator keberhasilan $80 \%$. Belum tercapainya indicator keberhasilan yang ditetapkan karena: (1) peserta didik belum terbiasa dalam mengimplementasikan model pembelajaran Discovery Learning, (2) masih ada peserta didik yang merasa sulit dalam merumuskan pertanyaan, (3) masih ada peserta didik yang tidak membuat laporan hasil eksperimen. Oleh karena itu peneliti dan kolaborator memutuskan untuk melanjutkan pada siklus II dengan melakukan perbaikan tindakan terhadap proses pembelajaran pada siklus I ditambah tindakan berupa kegiatan resitasi atau pemberian tugas berupa latihan soal pada setiap akhir pertemuan. Resitasi atau pemberian tugas tidak sama dengan PR tetapi lebih luas dari PR. Metode resitasi atau penugasan adalah metode pembelajaran yang menekankan pada pembacaan, pengulangan, dan pemeriksaan diri sendiri melalui sejumlah tugas yang diberikan oleh guru kepada peserta didik di luar jam pembelajaran dalam rentang waktu tertentu dan hasilnya dipertanggungjawakan kepada guru dengan tujuan untuk merangsang peserta didik aktif belajar baik secara individu maupun kelompok. Dalam penelitian ini yang dimaksud dengan resitasi atau pemberian tugas sesuai dengan pendapat Djamaroh dan Zein (2010), yaitu metode penyajian bahan dengan tugas tertentu dari guru agar peserta didik aktif melakukan kegiatan belajar, baik secara individual ataupun secara kelompok. Resitasi atau pemberian tugas menurut peneliti adalah metode pembelajaran yang menekankan pemberian tugas tertentu berupa Latihan soal-soal dari materi yang sudah diajarkan untuk memperdalam pengetahuan pada materi tersebut dan dipertanggungjawabkan kepada guru dalam kurun waktu tertentu.

\section{Siklus II}

Pelaksanaan siklus II terdiri dari tiga pertemuan dengan materi yang berbeda setiap pertemuan. Setiap pertemuan terdiri dari: (1) kegiatan pendahuluan, (2) kegiatan inti, dan (3) kegiatan penutup. Pada siklus II kegiatan pembelajaran hampir sama dengan siklus I dan menindaklanjuti kekurangan-kekurangan yang terjadi pada siklus I serta menambah kegiatan resitasi atau pemberian tugas di setiap akhir pertemuan. Implementasi model Discovery Learning dalam pembelajaran mengacu pada RPP yang telah disusun, diawali dengan pemberian stimulus oleh guru lalu memberi kesempatan peserta didik menemukan sendiri konsep dan fakta fisika melalui kegiatan praktikum dengan bantuan LKPD dan menambah kegiatan resitasi atau pemberian tugas di setiap akhir pertemuan. Setelah peserta didik melakukan kegiatan praktikum, guru memberikan umpan balik dengan mengajukan pertanyaan-pertanyaan yang berkaitan dengan penemuan konsep dari eksperimen/praktikum yang telah dilakukan. Kemudian masing-masing kelompok berdiskusi dan mempresentasikan hasil diskusi di depan kelas/laboratorium dan kelompok yang lain menanggapi. Peserta didik yang menjawab pertanyaan dengan benar memperoleh reward dari guru. Guru menanggapi hasil diskusi dari peserta didik dan memberi penguatan sekaligus menyimpulkan hasil temuan konsep pembelajaran tentang induksi elektromagnetik. Pada akhir pembelajaran guru memberi tugas berupa latihan soal-soal penerapan konsep dan peserta didik membuat laporan eksperimen/praktikum untuk dikumpulkan pada pertemuan berikutnya. Setelah dilakukan tindakan pada siklus II diperoleh data hasil observasi keterampilan berpikir kritis sebagaimana tampak pada tabel 3 di bawah ini.

Tabel 3. Data Keterampilan Berpikir Kritis pada Siklus II

\begin{tabular}{ccccc}
\hline No. & Skor Perolehan & $\begin{array}{c}\text { Frekuensi } \\
\text { Siklus II }\end{array}$ & $\begin{array}{c}\text { Persentase } \\
\text { \% }\end{array}$ & Kategori \\
\hline 1 & $7-9$ & 22 & 81,48 & Tinggi \\
2 & $4-6$ & 5 & 18,52 & Sedang \\
3 & $1-3$ & 0 & 0 & Rendah \\
& Jumlah & $\mathbf{2 7}$ & $\mathbf{1 0 0}$ & \\
\hline
\end{tabular}


Berdasarkan pada tabel 3 di atas, dapat diketahui bahwa keterampilan berpikir kritis kategori tinggi pada peserta didik yang mengikuti pembelajaran dengan implementasi model Discovery Learning dan penambahan kegiatan resitasi pada siklus II nampak adanya optimalisasi yang signifikan. Dari 27 peserta didik, 22 peserta didik atau 81,48\% memiliki kategori tinggi. Hal ini menunjukkan bahwa ada pengaruh yang signifikan pada keterampilan berpikir kritis peserta didik dengan implimentasi model Discovery Learning. Dengan demikian keterampilan berpikir kritis kategori tinggi pada siklus II sudah melampaui target indikator keberhasilan sebesar $80 \%$.

Optimalisasi keterampilan berpikir kritis dan penambahan kegiatan resitasi berdampak positif pada peningkatan hasil belajar. Data hasil belajar diperoleh setelah melakukan tes penilaian harian secara tertulis pada akhir pembelajaran siklus II. Hasil analisis data penilaian hasil belajar peserta didik kelas XII IPA.2 dalam proses pembelajaran siklus II diperoleh data sebagaimana tampak pada tabel 4 di bawah ini.

Tabel 4. Hasil Belajar Pada Siklus II

\begin{tabular}{clc}
\hline No. & \multicolumn{1}{c}{ Kriteria } & Hasil Siklus II \\
\hline 1. & Nilai Tertinggi & 95,00 \\
2. & Nilai Terendah & 65,00 \\
3. & Nilai Rerata (Rata-rata) & 75,00 \\
4. & Jumlah peserta didik yang tuntas & 22 \\
5. & Jumlah peserta didik yang tidak tuntas & 5 \\
6 & Prosentase Ketuntasan Belajar & $\mathbf{8 1 , 4 8 \%}$ \\
\hline
\end{tabular}

Berdasarkan tabel 4 di atas terlihat bahwa hasil belajar peserta didik pada siklus II untuk nilai rata-rata sudah nampak optimal sebesar 75,00 dengan ketuntasan belajar 81,48\%, sehingga sudah mencapai kriteria ketuntasan belajar klasikal yang ditetapkan yaitu $80 \%$ sebagai indikator keberhasilan penelitian. Dengan demikian penelitan sudah berhasil dan kegiatan penelitian tindakan kelas dihentikan sampai siklus II.

\section{B. Pembahasan}

Gambaran proses pembelajaran dan hasil belajar pada materi induksi elektromagnetik dengan implementasi model Discovery Learning adalah sebagai berikut: Pada keadaan awal / pra siklus, proses pembelajaran dilakukan dengan menggunakan metode ceramah, tanya jawab dan penugasan. Pembelajaran pada siklus I mulai dilaksanakan dengan implementasi model Discovery Learning, demikian pula pada siklus II. Dibandingkan dengan pra siklus, pembelajaran pada siklus I terjadi optimalisasi keterampilan berpikir kritis dan hasil belajar, namun belum melampaui indikator keberhasilan. Pada siklus II terjadi optimalisasi keterampilan berpikir kritis dan hasil belajar yang signifikan jika dibandingkan dengan siklus I. Perbandingan hasil observasi keterampilan berpikir kritis pada pra siklus sampai siklus II dapat dilihat dalam tabel 5 di bawah ini.

Tabel 5. Perbandingan Hasil Observasi Keterampilan Berpikir Kritis pada Antar Siklus

\begin{tabular}{ccccccccc}
\hline No & $\begin{array}{c}\text { Skor } \\
\text { Perolehan }\end{array}$ & $\begin{array}{c}\text { Pra Siklus } \\
\text { Frekuensi }\end{array}$ & \% & $\begin{array}{c}\text { Siklus I } \\
\text { Frekuensi }\end{array}$ & \% & $\begin{array}{c}\text { Siklus II } \\
\text { Frekuensi }\end{array}$ & \% & Kategori \\
\hline 1 & $7-9$ & 10 & 37,04 & 13 & 48,15 & 22 & 81,48 & Tinggi \\
2 & $4-6$ & 5 & 18,52 & 11 & 40,74 & 5 & 18,52 & Sedang \\
3 & $1-3$ & 12 & 44,44 & 3 & 11,11 & 0 & 0 & Rendah \\
& Jumlah & $\mathbf{2 7}$ & $\mathbf{1 0 0}$ & $\mathbf{2 7}$ & $\mathbf{1 0 0}$ & $\mathbf{2 7}$ & $\mathbf{1 0 0}$ & \\
\hline
\end{tabular}

Berdasarkan data pada tabel 5 di atas, dapat diketahui bahwa pelaksanaan pembelajaran dengan implementasi model Discovery Learning dapat untuk mengoptimalkan keterampilan berpikir kritis peserta didik. Optimalisasi keterampilan berpikir kritis peserta didik dibuktikan 
dengan peningkatan presentase keterampilan berpikir kritis dari siklus I ke siklus II untuk kategori tinggi. Pada kategori keterampilan berpikir kritis tinggi terjadi optimalisasi dari siklus I sebesar $48,15 \%$ menjadi $81,48 \%$ pada siklus II atau optimalisasi sebesar 33,33\%.

Untuk memudahkan dalam melihat hasil observasi keterampilan berpikir kritis pada tabel 5 di atas, maka dapat disajikan dalam bentuk grafik seperti pada gambar di bawah ini.

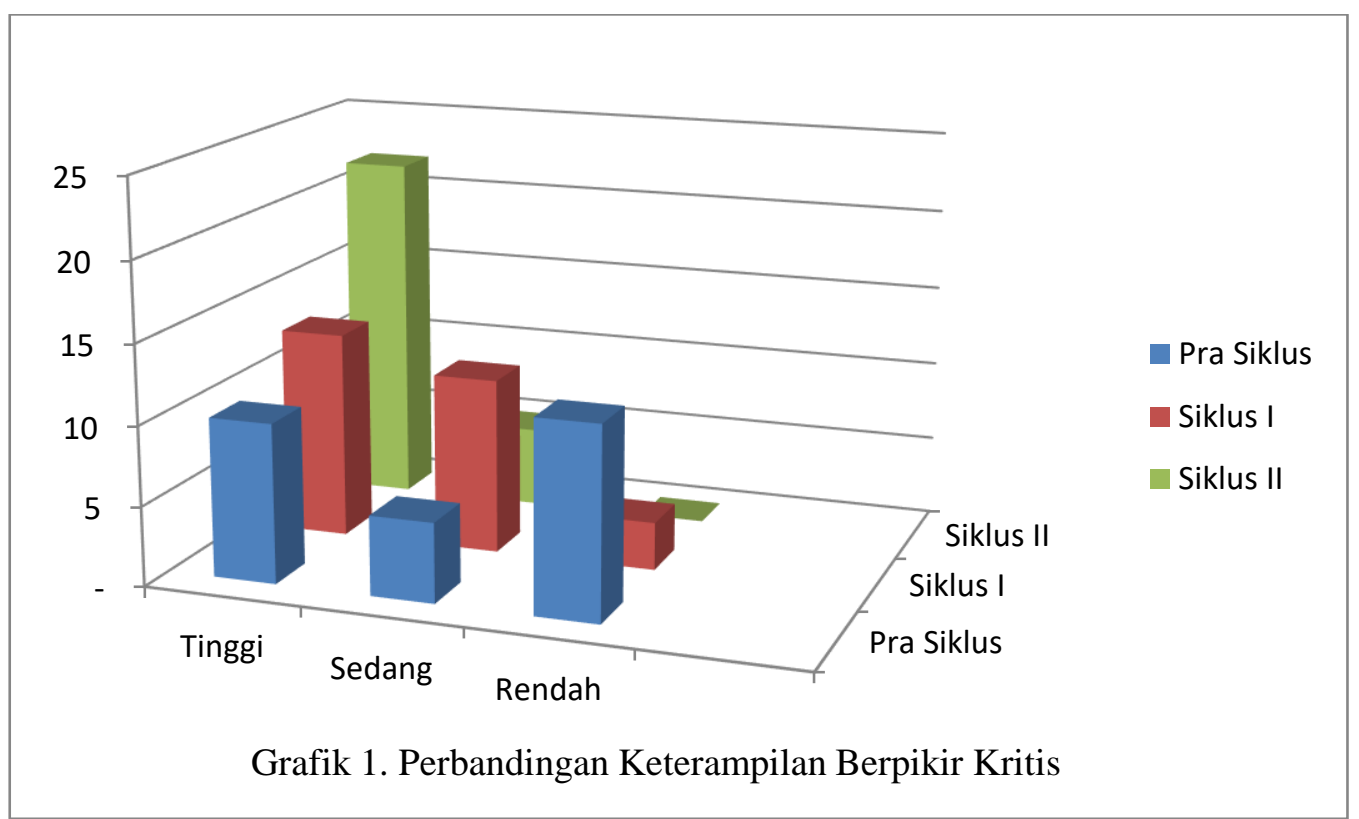

\section{Gambar 1. Grafik Perbandingan Hasil Observasi Keterampilan Berpikir Kritis pada Antar Siklus}

Berdasarkan data grafik 1 di atas terlihat ada optimalisasi keterampilan berpikir kritis kategori tinggi dari pra siklus, siklus I dan siklus II. Hal ini dapat disimpulkan bahwa pembelajaran dengan mengimplementasikan model Discovery Learning dapat mengoptimalkan keterampilan berpikir kritis kategori tinggi dari pra siklus 10 peserta didik $(37,04 \%)$ naik menjadi 13 peserta didik $(48,15 \%)$ pada siklus I dan naik menjadi 22 peserta didik $(81,48 \%)$ pada siklus II.

Optimalisasi keterampilan berpikir kritis kategori tinggi berdampak pada optimalisasi hasil belajar peserta didik. Hasil belajar diukur melalui tes penilaian harian pada pertemuan terakhir tiap siklus. Implementasi langkah-langkah pembelajaran dengan model Discovery Learning terbukti dapat mengoptimalkan hasil belajar peserta didik. Hal ini dapat dibuktikan dari perolehan data hasil belajar pada siklus I ke siklus II terjadi optimalisasi. Perbandingan hasil belajar pra siklus, siklus I, dan siklus II dapat ditunjukkan pada tabel 6 dan grafik 2 berikut ini.

Tabel 6. Perbandingan Hasil Belajar pada Antar Siklus

\begin{tabular}{ccccc}
\hline No. & Kriteria Hasil Belajar & Pra Siklus & Siklus I & Siklus II \\
\hline 1 & Nilai Tertinggi & 85,00 & 90,00 & 95,00 \\
2 & Nilai Terendah & 55,00 & 62,50 & 65,00 \\
3 & Nilai Rata-Rata & 68,15 & 71,02 & 75,00 \\
4 & Prosentase Ketuntasan Belajar & $\mathbf{5 5 , 5 6 \%}$ & $\mathbf{6 2 , 9 6 \%}$ & $\mathbf{8 1 , 4 8 \%}$ \\
\hline
\end{tabular}




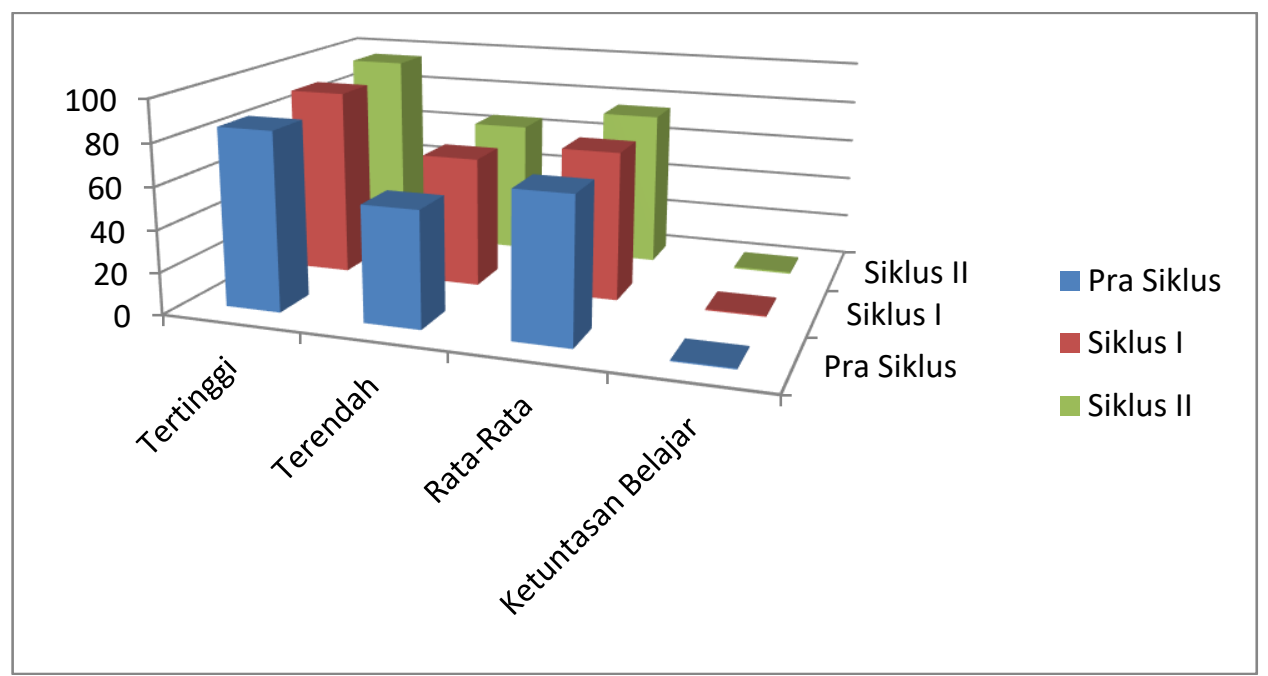

\section{Gambar 2. Grafik Perbandingan Hasil Belajar pada Antar Siklus}

Dari tabel 6 dan grafik 2 di atas terlihat bahwa nilai rata-rata hasil belajar pra siklus sebesar 68,15, nilai rata-rata siklus I sebesar 71,02, dan nilai rata-rata siklus II sebesar 75,00. Dengan demikian penerapan model Discovery Learning dapat mengoptimalkan hasil belajar dari rata-rata 71,02 pada siklus I menjadi 75,00 pada siklus II. Ketuntasan belajar pada pra siklus sebesar 55,56\%, siklus I sebesar 71,02\% dan siklus II sebesar 81,48\%. Hal ini berarti terjadi optimalisasi ketuntasan belajar klasikal peserta didik dari 71,02\% menjadi 81,48\%. Jadi, dapat disimpulkan bahwa model Discovery Learning dapat mengoptimalkan hasil belajar dari rata-rata 71,02 menjadi rata-rata 75,00 dan juga dapat mengoptimalkan ketuntasan belajar dari $71,02 \%$ menjadi $81,48 \%$. .

Implementasi model Discovery Learning berdampak positif pada perubahan situasi kelas dan peserta didik. Perubahan kondisi proses pembelajaran yang dilakukan peserta didik antara lain: mengumpulkan fakta yang relevan, mencatat hasil pengamatan, menghubungkan hasil-hasil pengamatan, menyusun dan menyampaikan laporan secara sistematis. Pada siklus II kondisi proses pembelajaran menjadi lebih baik karena sudah terbiasa dengan model Discovery Learning dan penambahan metode resitasi atau pemberian tugas pada setiap akhir pembelajaran. Dengan intervensi implementasi model Discovery Learning dalam pembelajaran, maka keterampilan berpikir kritis dan hasil belajar mengalami optimalisasi. Hal ini disebabkan implementasi model Discovery Learning kondisi peserta didik menjadi: (a) senang karena tumbuh rasa menyelidiki dan berhasil (b) mendorong berpikir dan bekerja atas inisiatif sendiri (c) mengembangkan bakat dan kecakapan individu, (d) mendorong berpikir intuisi dan merumuskan hipotesis sendiri. Hal ini sesuai dengan kelebihan pembelajaran model Discovery Learning (Budiningsih, 2005:41).

Berdasarkan perolehan data dari hasil implementasi model Discovery Learning terbukti dapat mengoptimalkan keterampilan berpikir kritis dan hasil belajar peserta didik, hasil dari penelitian ini sejalan dengan penelitian yang telah dilakukan sebelumnya. Penelitian sebelumnya dilakukan oleh Yulia Windarti, dkk (2016), meneliti tentang peningkatan kemampuan berpikir kritis dan hasil belajar melalui penerapan model Discovery Learning dalam pembelajaran tematik kelas 4 SD. Hasil penelitian yang dilakukan menunjukkan penerapan model pembelajaran Discovery Learning dapat meningkatkan kemampuan berpikir kritis dan hasil belajar siswa. Hasil penelitian tersebut menunjukkan terjadi peningkatan kemampuan berpikir kritis dan hasil belajar siswa.

Penelitian selanjutnya dilakukan oleh Rahayu Gustika, dkk (2017), meneliti tentang implementasi model pembelajaran penemuan (Discovery Learning) untuk meningkatkan keterampilan berpikir kritis dan hasil belajar fisika di SMAN 3 Bengkulu Tengah. Hasil penelitian yang dilakukan menunjukkan bukti penerapan model pembelajaran Discovery Learning dapat meningkatkan keterampilan berpikir kritis dan hasil belajar siswa. Hasil 
penelitian tersebut menunjukkan terjadi peningkatan keterampilan berpikir kritis dan hasil belajar siswa pada materi usaha dan energi di kelas X IPA.5.

\section{KESIMPULAN}

Berdasarkan hasil penelitian dan pembahasan diperoleh kesimpulan bahwa: (1) implementasi model Discovery Learning dapat mengoptimalkan keterampilan berpikir kritis secara signifikan pada materi induksi elektromagnetik di kelas XII IPA.2 terbukti aktivitas peserta didik dengan keterampilan berpikir kritis kategori tinggi meningkat dari siklus I ke siklus II sehingga terjadi optimalisasi sebesar 33,33\%, (2). implementasi model Discovery Learning dapat mengoptimalkan hasil belajar peserta didik pada mata pelajaran fisika tentang induksi elektromagnetik di kelas XII IPA.2 terbukti ada peningkatan nilai rata-rata dari siklus I ke siklus II sehingga terjadi optimalisasi sebesar 3,98, (3) implementasi model Discovery Learning dapat mengoptimalkan ketuntasan belajar terbukti dengan presentase ketuntasan belajar dari siklus I ke siklus II meningkat sebesar 18,52\% .

Berdasarkan penelitian yang telah dilakukan, maka disarankan perbaikan penelitian dimasa yang akan datang yaitu: (1) implementasi model Discovery Learning sebaiknya diterapkan pada materi yang sesuai agar model pembelajaran dan materi selaras, (2) implementasi model Discovery Learning sebaiknya dilengkapi alat-alat praktikum dengan jumlah yang cukup untuk beberapa kelompok kecil.

\section{DAFTAR PUSTAKA}

A.M, Sardiman. (2005). Interaksi dan Motivasi Belajar Mengajar. Jakarta: Rajawali Press. Arikunto, Suharsimi. (2002). Penelitian Tindakan Kelas. Jakarta: Bumi Aksara

Budiningsih, (2005). Model Discovery Learning. Jakarta: Pustaka Mandiri

Depdikbud. (2003). Undang-undang No 20 tahun 2003 tentang sisdiknas. Jakarta: Depdikbud

Rahayu Gustika, Indra Sakti, Desy Hanisa Putri. (2018). Implementasi Model Pembelajaran

Penemuan (Discovery Learning Model) Untuk Meningkatkan Keterampilan Berpikir

Kritis Dan Hasil Belajar Fisika Di SMAN 3 Bengkulu Tengah. Jurnal Kumparan Fisika

Volume 1 Nomor 1 2018: 1-6. DOI: https://doi.org/10.33369/jkf.1.1.1-6

Surya, Yohanes. (2004). Fisika untuk Semua. Jakarta: PT. Bina Sumber Daya MIPA

Slameto. (2003). Belajar dan Faktor-faktor yang Mempengaruhinya. Jakarta: Rineka Cipta.

Syah, M. (2004). Psikologi Pendidikan Dengan Pendekatan Baru. Bandung: PT Remaja Rosdakarya.

Yulita Windarti, Slameto, Eunice Widyanti S. Peningkatan Kemampuan Berpikir Kritis Dan Hasil Belajar Melalui Penerapan Model Discovery Learning Dalam Pembelajaran Tematik Kelas 4 SD. Jurnal Pendidikan Berkarakter. Volume 1 Nomor 1 April 2018: 150 - 155. DOI: https://doi.org/10.31764/pendekar.v1i1.353 